\title{
A small-scale cult centre in Southeast Turkey: Harbetsuvan Tepesi
}

\author{
Bahattin Çelik \\ Department of Archaeology, University of Ardahan, Ardahan, TR \\ bahattincelik@ardahan.edu.tr
}

\begin{abstract}
The present paper aims to assess the finds from Harbetsuvan Tepesi, which we consider a small-scale satellite settlement located some $7 \mathrm{~km}$ southwest of Karahan Tepe. The paper also endeavours to show analogous characteristics of Harbetsuvan Tepesi by comparing the site with PPN settlements in adjacent regions. The remains of a round-plan building, a recent discovery observed on the surface in Harbetsuvan Tepesi, which features T-shaped pillars, is particularly notable. The remains of this building, which has characteristics analogous to 'Enclosure F' at Göbekli Tepe, is extremely important, as it demonstrates that round-plan buildings were still in use during the early PPNB period.
\end{abstract}

IZVLEČEK - V članku vrednotimo najdbe iz najdišča Harbetsuvan Tepesi, t. j. manjše satelitsko naselje, ki leži ok. 7 km jugozahodno od najdišča Karahan Tepe. Prikazujemo tudi značilnosti, ki Harbetsuvan Tepesi vežejo na druga PPN naselja $v$ sosednjih regijah. Opozorili bi predvsem na ostanke okrogle stavbe, ki je bila nedavno odkrita na površini najdišča Harbetsuvan Tepesi, za katerega so značilni predvsem stebri $v$ obliki črke T. Ostanki te stavbe, ki ima podobnosti z 'ogrado F' na najdišču Göbekli Tepe, so pomembni, saj dokazujejo, da so bile okrogle stavbe navzoče tudi še v zgodnjem PPNB obdobju.

KEY WORDS - Pre-Pottery Neolithic; T-shaped pillar; Karahan Tepe; Göbekli Tepe; cult centre

\section{Introduction}

Recently discovered during surface surveys conducted in 2014, Harbetsuvan Tepesi settlement is located within the provincial borders of Şanliurfa (Urfa) province in southeast Turkey (Celik 2015a. 12-14; 2015b.81). Harbetsuvan Tepesi is located approx. $53 \mathrm{~km}^{1}$ east of Şanliurfa on a plateau known as the Tektek Mountains (Tektek Dağları) (Fig. 1). Similar to Göbekli Tepe, Karahan Tepe, Hamzan Tepe, and Sanlıurfa-Yeni Mahalle, PPN settlements positioned around the Harran plain in the Urfa Region, Harbetsuvan Tepesi settlement was also founded on a mesa at the eastern edge of the Harran Plain. The Harran Plain extends west of the settlement, which is on a hill that forms the western margin of the Tektek Mountains (Map 1).
The studies undertaken on the surface at the Harbetsuvan Tepesi settlement revealed depressions carved into the bedrock, and flint and obsidian tools. The finds recovered from the settlement point to the fact that it was used as a small-scale cult centre during the Pre-Pottery Neolithic period. Moreover, several T-shaped pillars, known from Nevali Cori, Sefer Tepe, Hamzan Tepe, and Göbekli Tepe, were also recorded on the surface. The study undertaken at the settlement further resulted in the discovery of reliefs that depict the fingers of a hand on a T-shaped pillar recovered from an area excavated by treasure hunters.

1 Several publications state this distance as $45 \mathrm{~km}$, as it is possible to access Harbetsuvan Tepesi from two different roads (see Celik 2015a.12). 


\section{Location}

Harbetsuvan Tepesi settlement is located approx. $714 \mathrm{~m}$ a.s.l., between $39^{\circ} 15^{\prime} 8,76^{\prime \prime}$ East, $37^{\circ} 2^{\prime}{ }^{\prime} 55,23^{\prime \prime}$ North ${ }^{2}$. The settlement was founded on mountainous highland terrain called the Tektek Mountains. This region forms the southernmost margin of the Urfa Plateau, which has high hills rather than mountains. In this region, which has no water sources, calcareous rocks are encountered frequently due to soil erosion. The sole source of water in the region is the creeks that spring to life and flow only after heavy rain. Therefore, even today cisterns in villages are used to collect rainwater for use during summer, when water is scarce.

The section of the Harbetsuvan Tepesi settlement that has survived covers an area of approx. $6000 \mathrm{~m}^{2}$. The settlement site is concentrated precisely on the peak of a rocky hill. Karahan Tepe settlement, considered to be a mega settlement dating to the PrePottery Neolithic period, is located some $7 \mathrm{~km}$ northeast of the settlement (Fig. 2). The Harran Plain, the most important plain in the region, is located some $5 \mathrm{~km}$ west of Harbetsuvan settlement. Flint deposits are present in the vicinity of Karahan Tepe settlement, $8 \mathrm{~km}$ northeast of Harbetsuvan Tepesi (Celik 2011.241). Moreover, abundant flint deposit outcrops at an area known as Recmelsuvan, $10 \mathrm{~km}$ south of the settlement, have also been noted (Celik 2015b. nitoring only of the interior areas of the Tektek Mountains. Zakzuk Bastion (Zakzuk Kalesi) located some $4 \mathrm{~km}$ north of Karahan Tepe lies at an elevation of approx. $750 \mathrm{~m}$. However, this hill provides only a distant view of the Harran Plain. The fact that both Harbetsuvan Tepesi and Karahan Tepe are within the Tektek Mountains arises from an extremely suitable environment for setting snares and traps for hunting at such localities. The studies conducted in the region revealed some evidences related to trapping areas 3 .

\section{Pre-Pottery Neolithic assemblage at Harbetsu- van Tepesi}

Harbetsuvan Tepesi was inhabited only during the Pre-Pottery Neolithic period. The finds discovered at the settlement are in the form of architectural remains and small finds, such as flint and obsidian tools, comprising 76 small finds and 3 architectural remains. Two of the architectural remains were exposed by illegal excavations, and include T-shaped pillars. The other architectural find is part of a limestone block, which is in an interior space.

\section{Architectural remains}

The architectural remains at Harbetsuvan Tepesi are numerous and still well-preserved. The T-shaped pillars, some of which are still standing, are scattered 82-83). The flint finds are abundant over the entire area of Harbetsuvan Tepesi, with the number of flint artefacts per $1 \mathrm{~m}^{2}$ being around 30. On the other hand, the closest basalt quarry to the settlement is $15 \mathrm{~km}$ northwest of the archaeological site.

This small-scale settlement on the eastern margin of the Harran Plain, together with nearby Karahan Tepe, was probably a satellite settlement of Karahan Tepe. The position of Harbetsuvan Tepesi is the best location for overlooking the Harran Plain, a strategic advantage that Karahan Tepe does not have (Map 1). The location of Karahan Tepe allows mo-

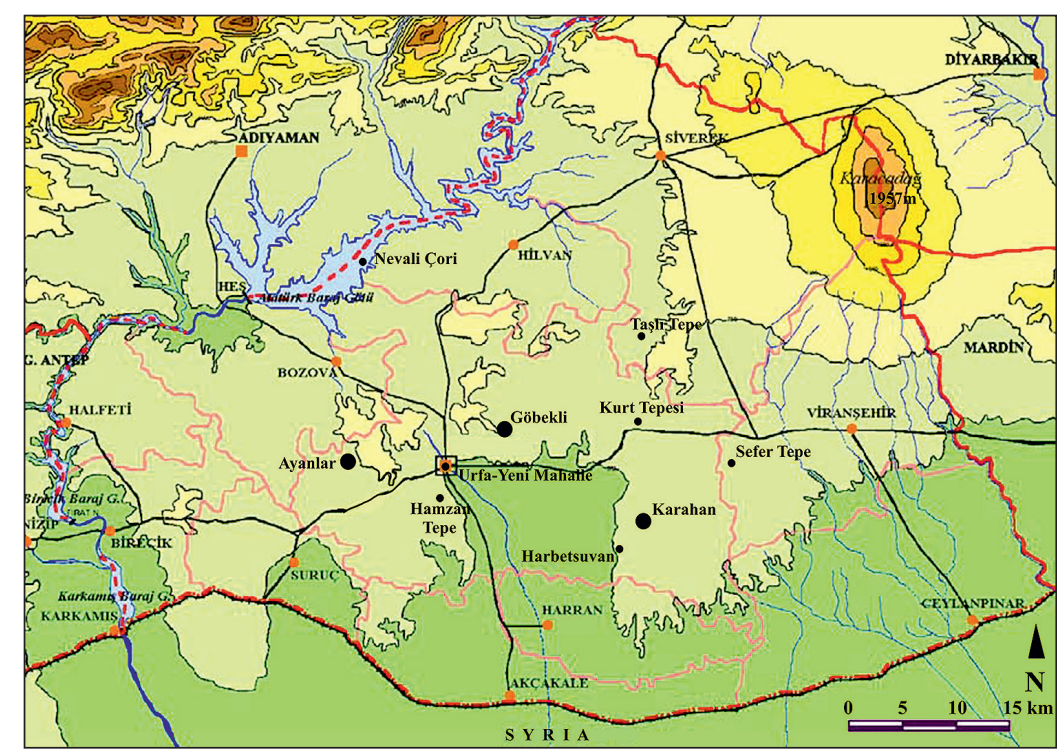

Map 1. Map illustrating settlements with pillars from the Pre-Pottery Neolithic Period (drawing M. S. Şahinalp).

\footnotetext{
2 Karahan Tepe settlement located northeast of Harbetsuvan Tepesi is positioned between $39^{\circ} 18^{\prime} 11,85^{\prime \prime}$ East and 37 ${ }^{\circ}{ }^{\prime 29} .16^{\prime \prime}$ North coordinates.

3 A further study is currently in progress concerning the trapping areas south of Harbetsuvan Tepesi.
} 
all around the entire surface of the site; only their capital sections are partially broken, almost $20-30 \mathrm{~cm}$ of which are visible from the surface. The pillars are arranged side by side at intervals of 1.5 to $2 \mathrm{~m}$; a total of 14 pillars were identified on the surface. The length of some of the pillars recovered at the settlement site due to illegal excavations varies from around 1 to $1.5 \mathrm{~m}$; they vary in thickness from 20 to $25 \mathrm{~cm}$, while widths range from 40 to $50 \mathrm{~cm}$. One of the pillars bears an imprint of the fingers of a hand and a girdle relief on one side (Fig. 3). However, no relief was observed on the other pillars. Another intact pillar was also discovered, again by illegal excavations (Fig. 4). This intact pillar lacks any relief, although the dimensions are identical to the dimensions of the pillars observed at Karahan Tepe (Celik 2000a.7; 2011.242).

The upper parts of walls are still visible in some areas, seemingly from the Neolithic period. Pillars arranged at intervals of 1.5 to $2 \mathrm{~m}$ adjacent to the wall were discovered in the interior section of such walls. Upon tracing the walls, it was observed that the structure suggests a round-plan building (Fig. 5). This building is similar to 'Enclosure F' discovered at Göbekli Tepe, three-quarters of which have been excavated and revealed (Dietrich et al. 2012.Fig. 12; Schmidt 2010.240, Fig. 15). 'Enclosure F' at Göbekli Tepe appears as a building attributed to Layer II in some publications (Schmidt 2007.276-277, Fig. 9), between Layers II and III in other publications (Schmidt 2010.240, Fig. 2), or as an uncertain building in some others (Dietrich et al. 2014.Fig. 2; Becker et al. 2012.16, 18, Abb. 3). The most interesting aspect of this building is that it is a round-plan structure resembling the architecture of Layer III, while the pillars are similar in size to pillars from Layer II. The round-plan building found at Harbetsuvan Tepesi is almost twice the size of 'Enclosure F' at Göbekli Tepe (Fig. 6).

No excavations are being undertaken at Karahan Tepe, so it is extremely difficult to make any conclusions. However, the site is dated to the same period as Layer II of Göbekli Tepe on the basis of the dimensions of the T-shaped pillars (Celik 2011.242-246). At Harbetsuvan Tepesi, on the other hand, the existence of a round-plan building, which is almost entirely exposed, may be testament to the existence of similar round-plan buildings with pillars at Karahan Tepe in the close vicinity of the site. The building discovered at Harbetsuvan Tepesi can be seen clearly from satellite images; the diameter is estimated to be approx. $20 \mathrm{~m}$.
One fractured limestone vessel fragment was discovered at Harbetsuvan (Fig. 7); most of these artefacts were found inside buildings. Similar vessel fragments with a diameter of approx. $50 \mathrm{~cm}$ have also been encountered at Göbekli Tepe (Dietrich et al. 2012.Fig. 11; 2014.Fig. 5), Karahan Tepe, and Ayanlar Höyük.

Three cavities were carved out of the bedrock to the north of the settlement. One of these is smaller, while the diameter of one larger cavity appears to be around $1.5 \mathrm{~m}$ and the depth around $80 \mathrm{~cm}$ (Fig. 8 ). This type of depression, also observed at Karahan Tepe (Celik 2011.242), Göbekli Tepe (BeileBohn et al. 1998.50, Abb. 20), Hamzan Tepe (Celik 2004.Fig. 3; 2006.Fig. 4; 2010.Figs. 5, 7-8), Kurt Tepesi (Celik 2015), and Domuzcurnu Tepesi (Güler, Celik 2015), was probably built to collect rainwater.

Rectangular buildings approx. $4 \mathrm{~m}$ wide and $7 \mathrm{~m}$ long built side by side are present on the western slope of the settlement site (Fig. 9). The wall stones of such buildings are large, untrimmed and flat. The building appears to have no entrances. No ceramic fragments were discovered in the buildings, but flint blades and chips were recovered. At present, we do not know the purpose of the buildings. However, ruined buildings similar to these are also found on the side slopes south of Harbetsuvan Tepesi.

Another small-scale settlement covering an area of approx. $1000 \mathrm{~m}^{2}$ was discovered on a hill $350 \mathrm{~m}$ southwest of Harbetsuvan Tepesi. This settlement contains pillar fragments and architectural remains, while flint and obsidian blades and chips were also recovered on the surface. The purpose of this settlement also remains unknown.

\section{Finds with depictions}

Reliefs were discovered on one pillar recovered from Harbetsuvan Tepesi by illegal excavations (Fig. 3). The reliefs on the side of the pillar depict the fingers of a hand and a girdle, which also occur at Göbekli Tepe (Schmidt 1999.Taf. 9.2; 1997/98.163-164, Abb. 13), Nevali Çori (Schmidt 2010.Fig. 5), and Kurt Tepesi (Güler, Celik 2015.78-79, Res. 2; Çelik 2015c.Fig. 2). An interesting fact here is that, while the pillars bear reliefs depicting the fingers of a hand and a girdle, no reliefs depicting arms, as observed on the pillars at Nevali Çori and Göbekli Tepe, were found. Something similar is true of the single pillar discovered at Kurt Tepesi. This pillar lacks reliefs depicting either arms or fingers; only the girdle and chevron patterns were found (Celik 2015a.12, Fig. 
5). The fact that both examples lack arm patterns point to the possibility that these types of pillar were probably inserted into the walls. One pillar with a broken capital part inside the 'Lions Pillar Building' at Göbekli Tepe also has similar reliefs depicting the fingers of a hand and a girdle. This pillar too stands as if inserted into the wall (Schmidt 1997/98.Abb. 13; 1999.Taf. 2, 9.2).

\section{Technology and typology}

A total of 77 small finds were acquired from the Harbetsuvan Tepesi settlement site. Of these, the Neolithic find assemblage comprises flint (65 artefacts) and obsidian (12 artefacts). The flint tools consist of arrowheads, scrapers, perforators, burins, crested blades, cores, and sickle blades with silica shine. The obsidian tools are in the form of blade pieces and flakes (Fig. 10).

An abundant amount of flint and a small amount of obsidian finds were acquired from Harbetsuvan Tepesi. The blade industry contributed most to the flint and obsidian finds, with different types of blades accounting for the highest proportion in the flint tools.

The flint tools are represented by 60 finds in the entire flint assemblage. Other flint artefacts are 1 core (Fig. 10.26) and 4 crested blades (Fig. 10.32-35), which are core replenishment parts. The flint tools consist of 48 arrowheads and arrowhead fragments (Fig. 10.1-20), 5 perforators (Fig. 10.21-25), 2 end scrapers (Fig.10.36-37) and 5 silica sickle blades (Fig. 10.27-31). With respect to all the flint tools discovered at Harbetsuvan Tepesi, the ratio of arrowheads is $74 \%$, while the ratio of arrowheads recovered from Göbekli Tepe is only 20\% (Schmidt 2001. 51-52, Fig. 9; Beile-Bohn et al. 1998.59), and 66.2\% at Karahan Tepe (Celik 2011.Tab. 2).

The raw material is high-quality flint. During the studies conducted in the area, flint deposits were encountered $8 \mathrm{~km}$ northeast and $10 \mathrm{~km}$ south of the archaeological site. The cores discovered at this site are only bipolar cores (Fig. 10.26). Regarding the colour distribution of all the flint finds discovered at the site, 32 finds are grey, 8 are dark grey, 22 are dark brown, and 3 are light brown. There are $12 \mathrm{ob}-$ sidian finds, but no tools were discovered among these (Fig. 10.38-46); the finds comprise 10 blade fragments and 2 flakes.

When we examined the flint tools, we came across tool types that in terms of their typology date to the
Pre-Pottery Neolithic period. Arrowheads comprised the majority of the finds, with the Byblos type being the most common. A detailed study of the arrowheads reveals their resemblance to arrowheads encountered in the region, where they are dated from the late PPN A to the middle of PPN B (Cauvin 1994. 78-95). Arrowheads similar to these were also found at settlements such as Karahan Tepe (Celik 2011. Fig. 18.4, 6, 8-9), Göbekli Tepe (Schmidt 2001.52, Figs. 10/3, 11/5), and Mureybet (Cauvin 1994.79).

Unidentifiable arrowheads are represented with a total of 46 finds (Fig. 10.5-20). When we take into consideration the blade width and thickness of all arrowheads, the arrowhead piece should have an upper and a lower section. Currently, we have no information on the shape of such arrowheads. However, arrowheads similar with respect to the shaft section in particular are known from Karahan Tepe (Celik 2011.Fig. 18.4, 6). Total of 4 intact arrowheads (Fig. 10.1-4) are discovered, where arrowheads similar to these are also known from Karahan Tepe (Celik 2011.Figs. 18.1, 19.1).

\section{Concluding remarks}

The most striking characteristic of Harbetsuvan Tepesi is that it is a small-scale settlement like Sefer Tepe, Taşlı Tepe, and Kurt Tepesi. Moreover, the settlement contains only Pre-Pottery Neolithic finds. It is highly possible that Harbetsuvan Tepesi is a smallscale cult centre with T-shaped pillars, just like at Sefer Tepe, Kurt Tepesi, and Taşlı Tepe. The surface surveys conducted south of Harbetsuvan Tepesi revealed numerous domestic settlement sites dating to the Pre-Pottery Neolithic period (Celik 2015b.81-83, Map 1). A similar occurrence was observed in the area surrounding Sefer Tepe settlement (Güler et al. 2013.294-297, Map 1), which might be evidence that Neolithic settlements with pillars are cult centres, while other domestic settlements lay in the hinterland.

The closest settlements contemporaneous with Harbetsuvan Tepesi during the Pre-Pottery Neolithic period are Karahan Tepe (7km north-east), Kurt Tepesi (20km north), Taşlı Tepe (35km north), Sefer Tepe (26km north-east), Sanliurfa-Yeni Mahalle $(43 \mathrm{~km}$ west), and Göbekli Tepe and Hamzan Tepe settlements, which are located approx. $40 \mathrm{~km}$ to the northwest. The architectural remains and small finds discovered at Harbetsuvan Tepesi have identical characteristics with finds from the Karahan Tepe, Taşl Tepe, Kurt Tepesi, Sefer Tepe, Hamzan Tepe, Şanlıur- 
fa-Yeni Mahalle, and Göbekli Tepe settlements. The cavities located north of the settlement carved out of the bedrock, on the other hand, resemble the depressions discovered at the Karahan Tepe, Göbekli Tepe, Hamzan Tepe, Domuzcurnu, and Kurt Tepesi settlements.

The currently exposed section of Harbetsuvan Tepesi greatly resembles the pillars in Layer II of Göbekli Tepe. In particular, a building similar to 'Enclosure F' at Göbekli Tepe is visible on the surface of Harbetsuvan Tepesi. The walls of the building remains with a diameter of approx. $20 \mathrm{~m}$ are clearly visible and exposed on the surface. The presence of pillars inserted into the walls points to the fact that this is a cult building. The ruins cover $1 / 6$ of the entire Harbetsuvan Tepesi settlement. In the light of all these finds, Harbetsuvan Tepesi appears to be contemporaneous with the upper layers of Göbekli Tepe and Layer III of Nevali Çori.

The pillars discovered in situ on the surface of the Karahan Tepe site were also discovered at Harbetsuvan Tepesi. However, although the capital sections of the pillars at Karahan Tepe were recovered intact, the capital section of all the pillars at Harbetsuvan Tepesi were broken and fractured for unknown reasons (Fig. 11). The fact that the settlement contains no Palmyra points or Cayönü tools enables us to date this settlement to the Early Pre-Pottery Neolithic Period Phase B (EPPNB).

Future excavations to be conducted at the Harbetsuvan Tepesi settlement site will help reveal that smallscale cult centres could have existed alongside largescale cult centres such as Karahan Tepe and Göbekli Tepe.

\section{ACKNOWLEDGEMENTS}

The studies conducted in 2014 and 2015 were undertaken with significant contributions from the Turkish Historical Society (Türk Tarih Kurumu), Mehmet Ekinci, the Mayor of Sanlurfa Eyyübiye Borough, Ardahan University Scientific Research Project No. 2016/2, and Mrs. Iffet Özgönül from Peten Tourism and Advertising.

\section{References}

Becker N., Dietrich 0., Götzelt T., Köksal-Schmidt C.., Notroff J. and Schmidt K. 2012. Materialien zur Deutung der Zentralen Pfeilerpaare des Göbekli Tepe und weiterer Orte des obermesopotamischen Frühneolithikums. Zeitschrift für Orient-Archaeologie 5: 14-43.

Beile-Bohn M., Gerber C., Morsch M. and Schmidt K. 1998. Frühneolithische Forschungen in Obermesopotamien. Göbekli Tepe und Gürcütepe. Istanbuler Mitteilungen 48: $5-78$.

Cauvin J. 1994. Naissance des divinitès, naissance de l'agriculture. La révolution des symboles au Néolithique. Editions Centre National de la Recherche Scientifique. Paris.

Celik B. 2000. A New Early-Neolithic Settlement: Karahan Tepe. Neo-Lithics 2(3): 6-8.

2004. A New Early-Neolithic Settlement: Hamzan Tepe. Neo-Lithics 2(4): 3-5.

2006. A New Lower Paleolithic Open Air Station and Early Neolithic Settlement. In Hayat Erkanal'a Armagan, Kültürlerin Yansıması/Studies in Honor of Ha- yat Erkanal, Cultural Reflections. Homer Kitapç1lı ve Yayınevi Ltd. Şti. İstanbul: 222-224.

2010. Hamzan Tepe in the Light of New Finds. Documenta Praehistorica 37: 257-268.

2011. Karahan Tepe, a New Cult Centre in the Urfa Area in Turkey. Documenta Praehistorica 38: 242-253.

2015a. Differences and Similarities between the Settlements in Şanlıurfa Region where "T" Shaped Pillars are Discovered/Sanlıurfa Bölgesinde "T" Sekilli Dikmetas Bulunan Yerleşimlerin Farklılık ve Benzerlikleri. Türkiye Bilimler Akademisi Arkeoloji Dergisi 17: 9-24.

2015b. Şanlıurfa Ili Yüzey Araștırması. Ardahan Üniversitesi İnsani Bilimler Dergisi. Belgü 2: 79-99.

2015c. Neolithic Settlements of Şanlıurfa in Southeastern Turkey. In E. Laflı, S. Patacı (eds.), Recent Studies on the Archaeology of Anatolia. British Archaeological Reports IS 2750. Oxford: 441-452.

Dietrich 0., Köksal-Schmidt Ç., Kürkçüoğlu C., Notroff J. and Schmidt K. 2014. Göbekli Tepe. Preliminary Report 
on the 2012 and 2013 Excavation Seasons. Neo-Lithics 14(1): 3-17.

Dietrich 0., Heun M., Notroff J., Schmidt K. and Zarnkow M. 2012. The role of cult and feasting in the emergence of Neolithic communities. New evidence from Göbekli Tepe, south-eastern Turkey. Antiquity 86: 674-695.

Güler M., Çelik B. and Güler G. 2012. Viranşehir İçesinden Yeni Çanak Çömleksiz Neolitik Dönem Yerleşimleri. / New Pre-Pottery Neolithic Settlements from Viranșehir District. Anadolu/Anatolia 38: 157-180.

Güler, M., Çelik B. 2015. Şanlıurfa Bölgesi Neolitik Dönem Araştırmaları. Ardahan Üniversitesi İnsani Bilimler Dergisi. Belgü 1: 75-102.

Schmidt K. 1997/1998. Stier, Fuchs und Kranich- der Göbekli Tepe bei Sanlıurfa und die Bilderwelt des oberme- sopotamischen Frühneolithikums. Nürnberger Blätter zur Archäologie 14: 155-170.

1999. Frühe Tier und Menschenbilder vom Göbekli Tepe, Kampagnen 1995-1998. Ein kommentierten Katalog der Grossplastik und der Reliefs. Istanbuler Mitteilungen 49: 5-21.

2001. Göbekli Tepe, Southeastern Turkey. A preliminary report on the 1995-1999 excavations. Paléorient 26 (1): $45-54$.

2007. Göbekli Tepe: santuarios de la Edad de Piedra en la Alta Mesopotamia. Boletín De Arqueología Pucp 11: 263-288.

2010. Göbekli Tepe: the Stone Age Sanctuaries. New result of ongoing excavations with a special focus on sculptures and high reliefs. Documenta Praehistorica 37: 239-256.

\section{$\therefore$}

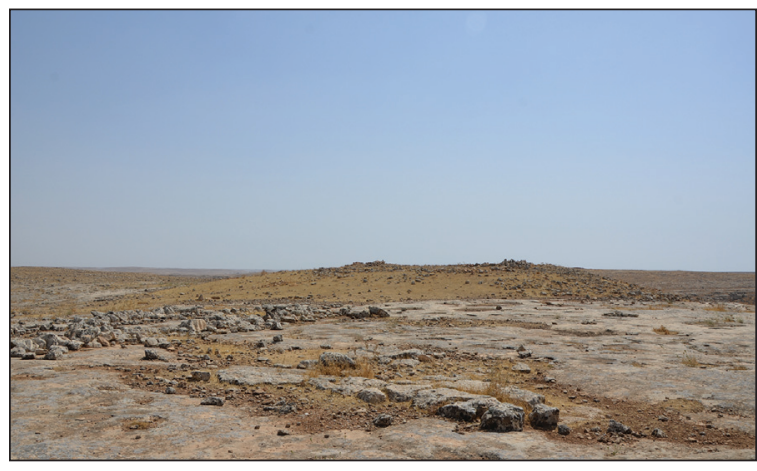

Fig. 1. View of Harbetsuvan Tepesi from the north (photo B. Celik).

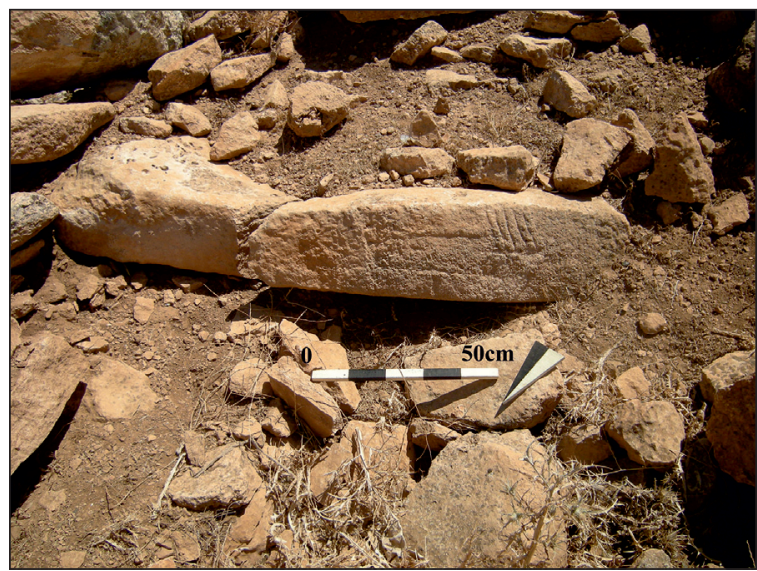

Fig. 3. The pillar with finger relief unearthed at Harbetsuvan Tepesi (photo B. Colik).

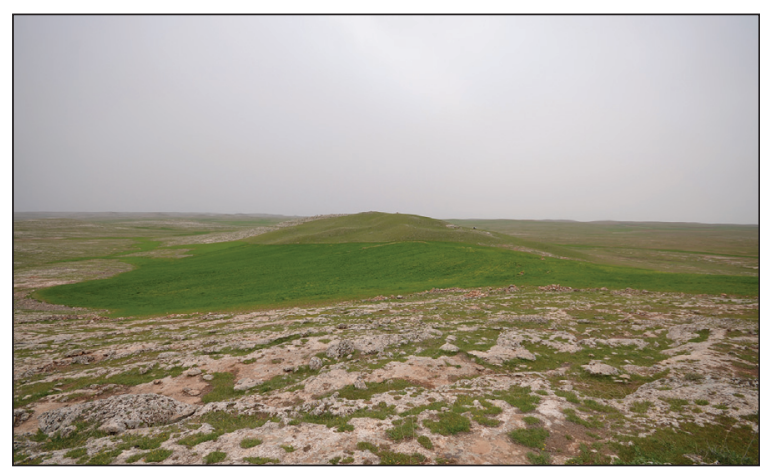

Fig. 2. View of Karahan Tepe from the east (photo B. Celik).

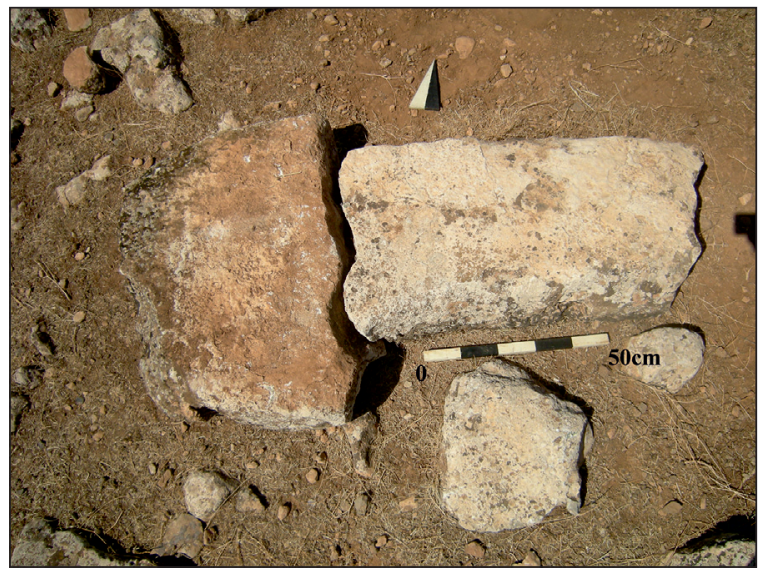

Fig. 4. An intact pillar at Harbetsuvan Tepesi (photo B. Celik). 


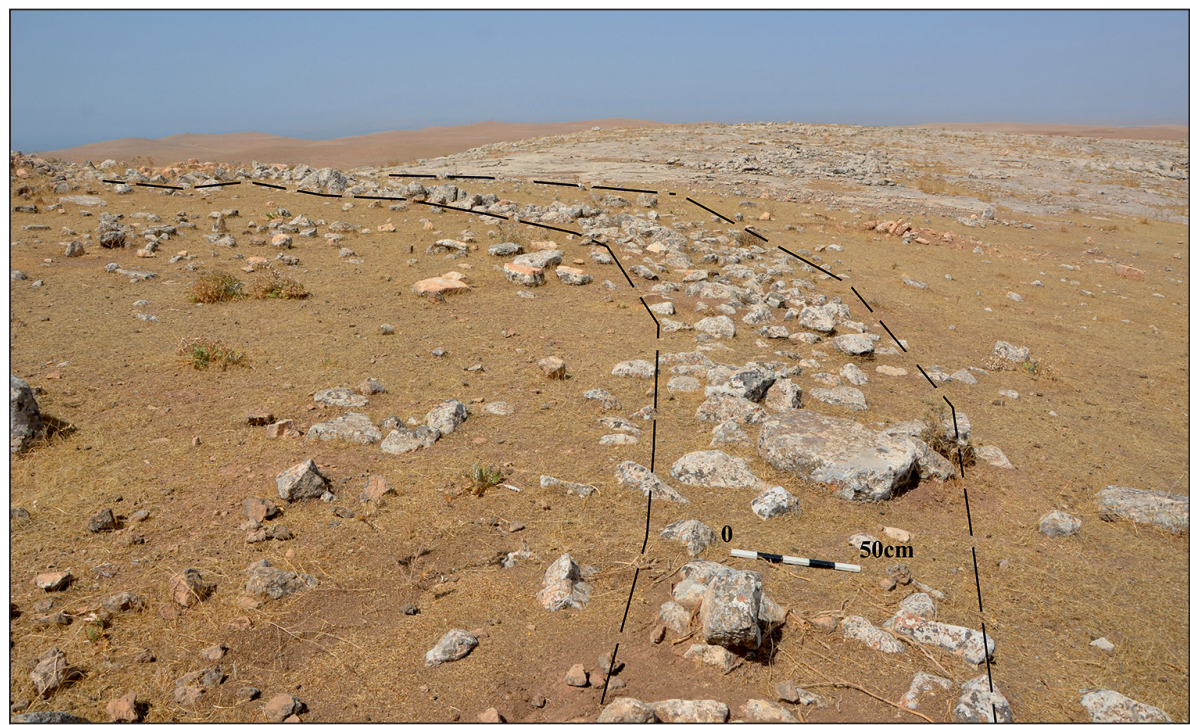

Fig. 5. View of the ruin of the round-plan building from the east (photo B. Celik).

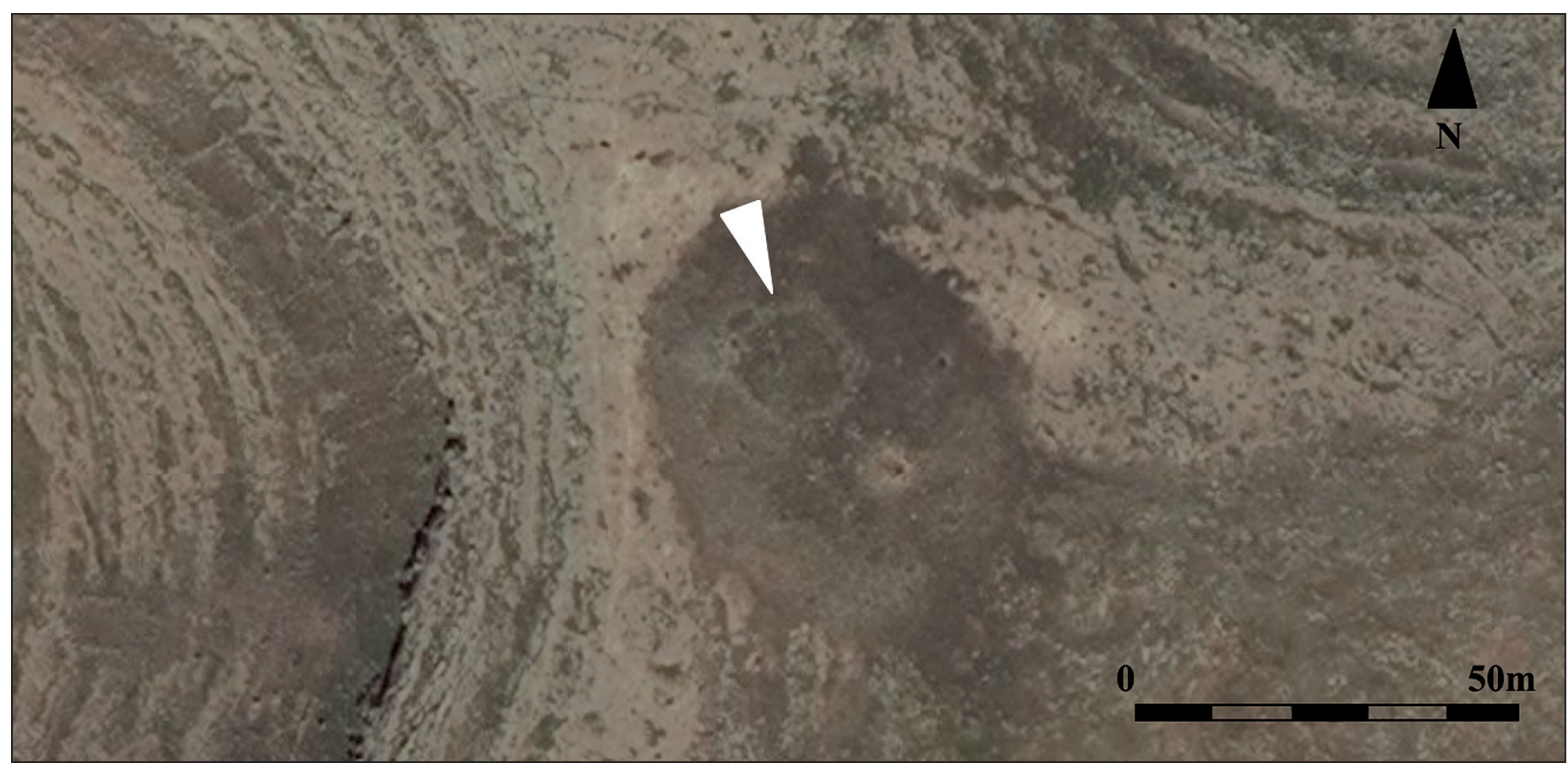

Fig. 6. Aerial view of the ruin of the round-plan building (photo B. Ceelik).

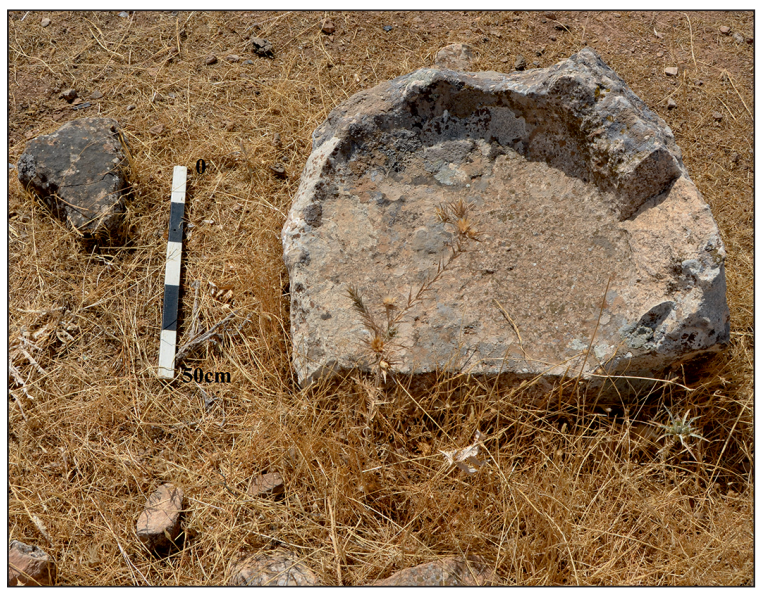

Fig. 7. Limestone vessel fragment from Harbetsuvan Tepesi (photo B. Celik).

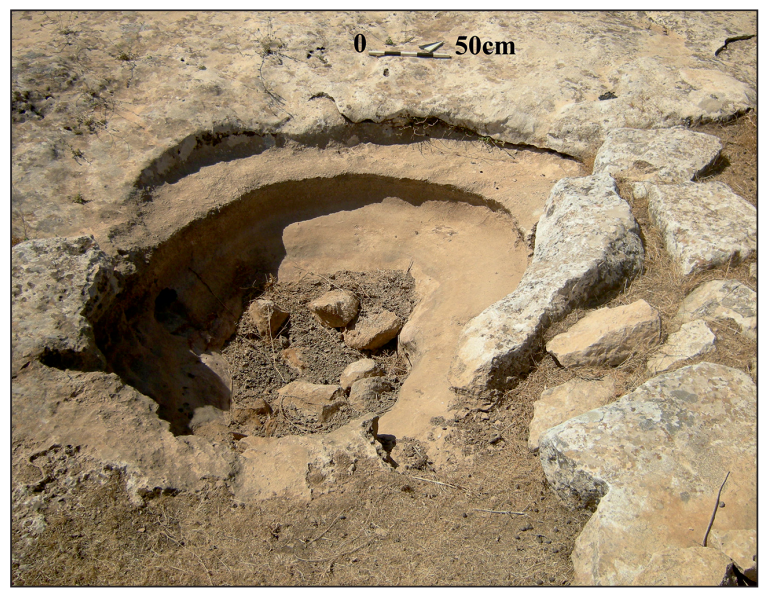

Fig. 8. Larger cavity carved out of the bedrock from Harbetsuvan Tepesi (photo B. Çelik). 


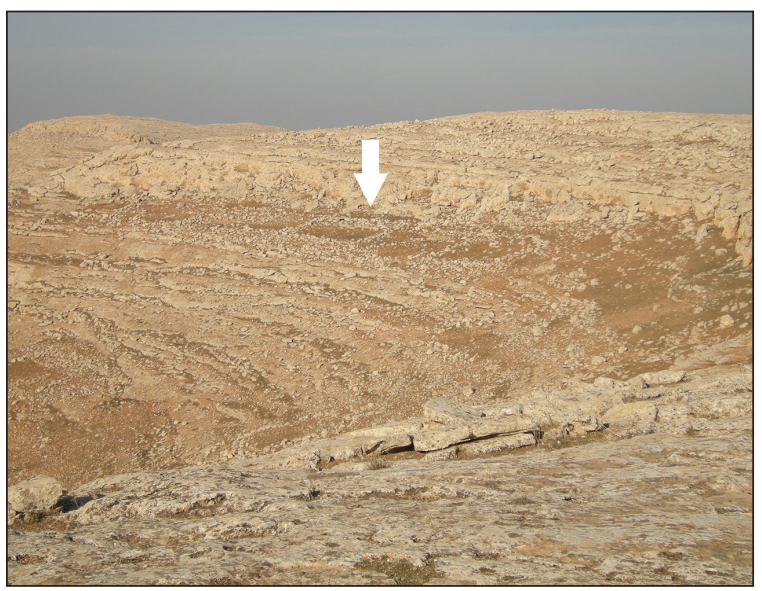

Fig. 9. View of the rectangular-plan buildings located on the western slope of Harbetsuvan Tepesi (photo B. Celik).

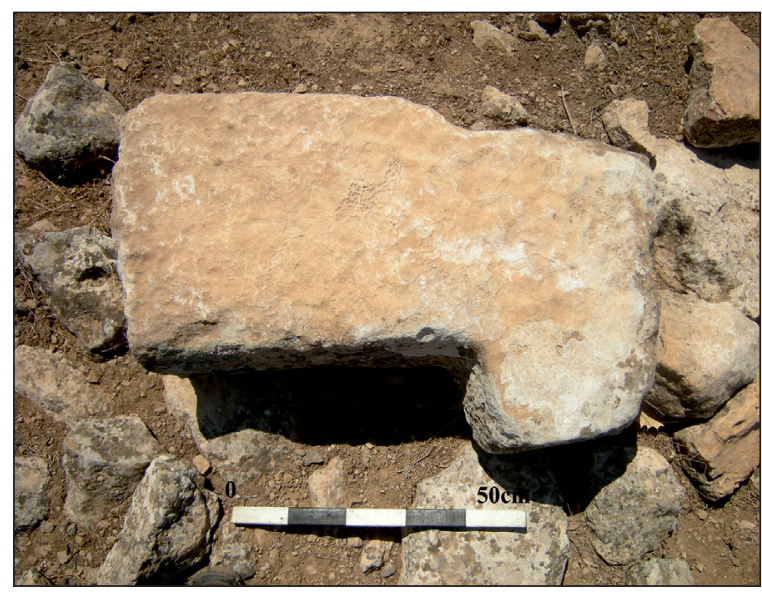

Fig. 11. An example of a broken pillar from Harbetsuvan Tepesi (photo B. Celik).

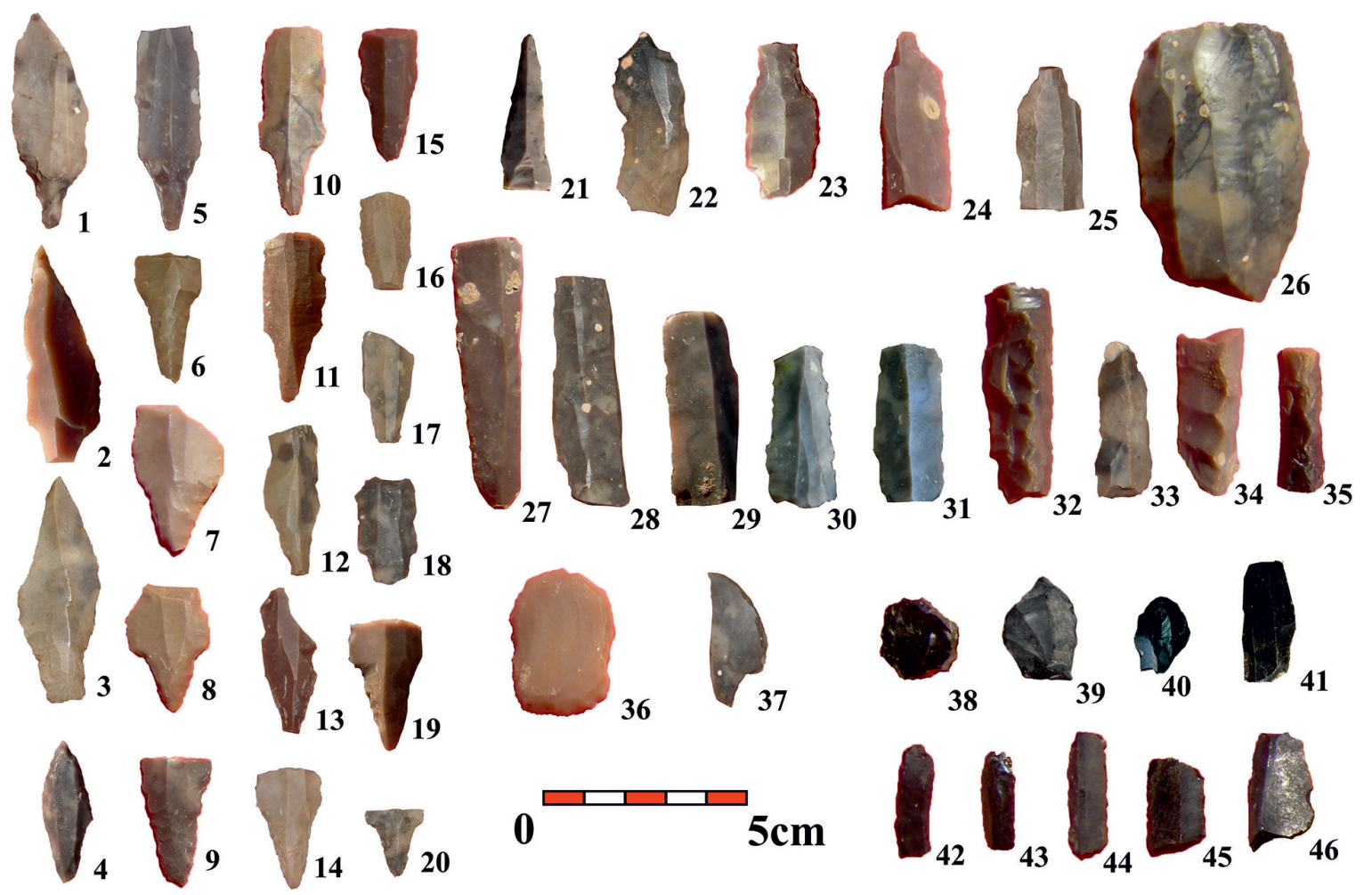

Fig. 10. Neolithic tools from Harbetsuvan Tepesi (photo B. Celik). 